\title{
CREATIVE TRANS-BORDER COOPERATION IN THE FIELD OF OPERATIONS RESEARCH AND SUSTAINABLE DEVELOPMENT IN CIVIL ENGINEERING
}

\author{
Oleg KAPLIŃSKI@1, Tatjana VILUTIENĖ®i] $2^{*}$ \\ ${ }^{1}$ Institute of Architecture and Physical Planning, Poznań University of Technology, Poznań, Poland \\ ${ }^{2}$ Department of Construction Management and Real Estate, Vilnius Gediminas Technical University, \\ Vilnius, Lithuania
}

Received 12 October 2021; accepted 26 November 2021

\begin{abstract}
The paper presents an overview of the history and achievements of trans-border cooperation in the Lithuania-Germany-Poland triangle in planning instruments in Construction Management, decision-making theory, application of Operational Research, and Multiple Criteria Decision Making (MCDM) methods in Civil Engineering and sustainable development. The cooperation and results of the Colloquiums with 35 years of tradition, their multidimensional nature is underlined. The research instruments, methods, studied phenomena are reviewed and characteristic applications in engineering and economics are presented. The knowledge and combined efforts of three academic centers have created a synergy which set in motion many original methods and spectacular implementations. The Colloquium calendar and the evolution of organizational forms are presented along with the inclusion of the informal EURO Working Group on Operations Research in Sustainable Development and Civil Engineering.
\end{abstract}

Keywords: scientific cooperation, operations research, MCDM, decisions, variants, micro and macroeconomics, sustainable development, civil engineering, EURO Working Group ORSDCE, review.

JEL Classification: C02, C39, C44, C61, C70.

\section{Introduction}

Traditional methods of optimization, statistics and econometric analysis used in an engineering context are based on the assumption that the problem is well formulated, and decisionmakers typically evaluate a single goal, an evaluation criterion, or an approach. In reality, however, the modeling of engineering problems is based on a different logic, the conflicting goals of decision-makers that leads to the use of multiple criteria and the complex, subjective and diverse nature of the evaluation process. In this context, multi-objective methods con-

\footnotetext{
${ }^{*}$ Corresponding author. E-mail: tatjana.vilutiene@vilniustech.lt
} 
tribute to the solution of engineering problems; help to identify optimal alternatives, considering the conflicting goals of different stakeholders. Awareness of the necessity, importance and benefits of the multi-criteria decision-making methods forced several scientists to form a steering group that has set itself the task of developing and promoting the application of such methods in civil engineering.

This article describes the evolving scientific cooperation of the promoters of the multicriteria decision-making methods that received support and was held with great esteem. This cooperation took the form of systematic scientific seminars since 1986, which the organizers called "Colloquia". The main goal of the colloquia was to combine the capabilities of researchers in the development and application of operations research methods to solve problems in the construction sector. Thus, we are now celebrating the 35th anniversary of the implementation of an idea, which, in this case, has become almost an "institution". This "institution" operated only under the shield of an agreement between universities.

Until 2009, research areas were limited to operations research in construction. Later, the idea was raised to analyze the operations research in civil engineering within the context of sustainable development. The idea of the new direction of research arose from the understanding that there was a lack of a comprehensive approach and a synthesis of models linking different tasks. Modern tools for evaluation and measurement of progress that combine the essential aspects of sustainable development are needed to enhance the integration of the sustainability concept.

Sustainable development of cities and their infrastructure is one of the priority tasks of the modern world. Sustainability priorities combine crosscutting issues of environment protection, energy efficiency, optimization of mobility and technology penetration, with solutions involving different levels of governing institutions and groups pursuing various goals. Construction industry organizations are constantly engaged in a variety of projects throughout their life cycle. The success of the project depends on the resources of the organization, the efficiency of management; moreover, the success of the organization is influenced by the results and success of each project. The various actors in the construction process (public authorities, the community, actors in the construction sector, research centers) also influence the activities of the construction sector, mainly through regulatory mechanisms, information dissemination, training and research. New working methods and technologies that could increase process efficiency will have a great impact on construction industry projects in the future.

Since then the sustainability issues in civil engineering were an integral part of all researches in collaborating centers. Lithuanian, German and Polish research centers were primarily involved in the joint research. After a series of visits and discussions on how to develop effectively scientific cooperation, regional cooperation has evolved into international cooperation, and the Working Group on Operational Research for Sustainable Development and Civil Engineering (ORSDCE) was established.

The paper is organized as follows: Section 1 describes the nature of trans-border cooperation in form of Colloquia. A new form of cooperation - EURO Working Group ORSDCE is presented in Section 2. The character of research topics is discussed in Section 3. The nature of both cooperation formulas (the Colloquia and Working Group ORSDCE) together with the results is multidimensional; hence, their review has been divided into theoretical (methods) 
and presented in Section 4. While practical (implementations) are presented in Section 5. Some important achievements of the collaboration are presented in Section 6. The review was based on the publications (mainly articles) published by those scientists who directly participated in the above-mentioned bodies. Articles by other authors, in which the methods presented in our community were used or assessed, were also included.

\section{The nature of trans-border cooperation in form of Colloquia}

The key topic of the Colloquia was the issue of decision-making in civil engineering. Over time, the subject matter was evaluated and changed. Starting with such topics as "Methoden der bautechnologischen Entscheidung" (the first Colloquium, Leipzig 1986); "Planning Instruments in Construction Management"; "Modern instruments in management" it evolved to such topics as "Sustainable decisions in build environment"; "Sustainable development in Civil Engineering and multi-attribute decision making" (the last Colloquium, Vilnius 2019).

The calendar of the colloquiums and the characteristic dominating topics are presented in Figure 1. The venues are also listed. The Colloquiums took place regularly every two years, organized by the universities in Leipzig, Vilnius and Poznań. One meeting was held in Aachen (1999).

Not only the subject matter of the Colloquia has changed. Gradually, the formula of these meetings evolved, as the terms of cooperation changed. The basis of the initial meetings was the so-called hard currency-free exchange. During this period, the possibilities of travelling abroad were limited. The self-organization of scientific life and the necessity of its existence was the philosophy behind such a formula. Its characteristic elements were mutual consultations and the first publications (individual or joint), already treated as international publications. Presentations of achievements during the Colloquia were held in Russian and German. The first studies were also published in these languages.

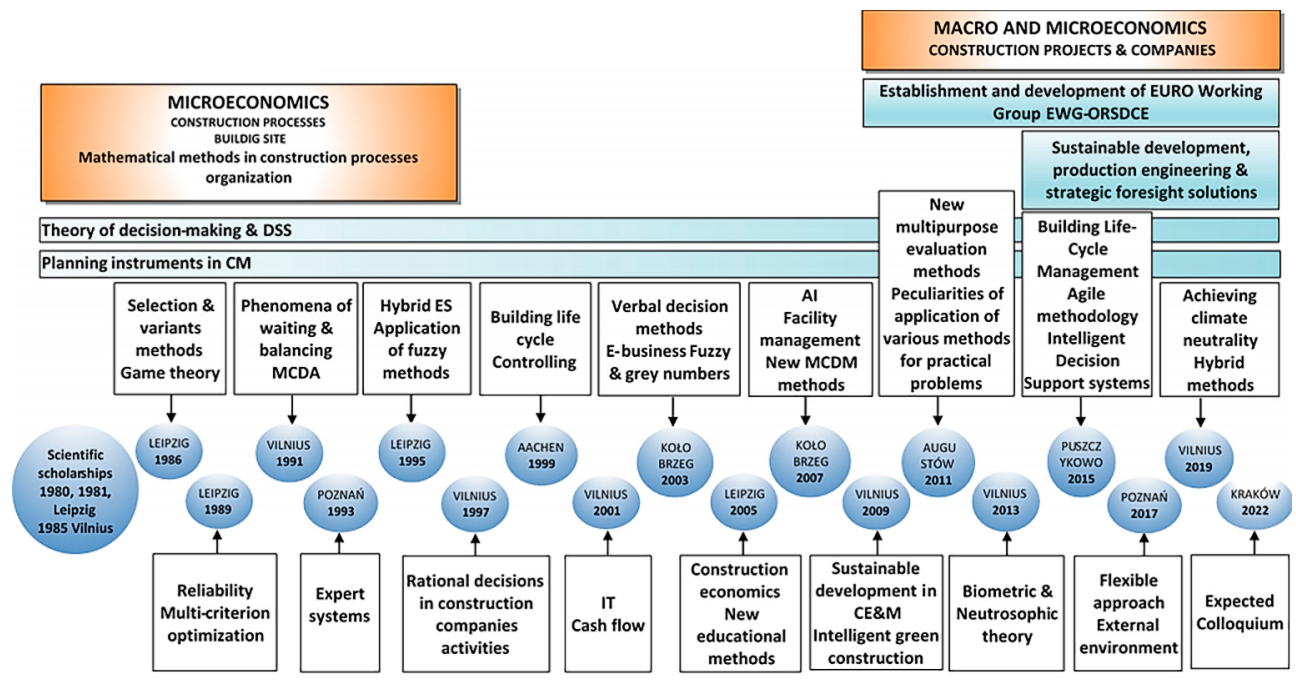

Figure 1. Colloquia calendar and dominant topics 
The initiation of the Colloquia was preceded by contacts in 1975-1985 and participation in congresses and scientific internships. A joint publication originates from this period (Wagner et al., 1985). However, these sporadic meetings soon turned out to be insufficient, that is why Prof. E. K. Zavadskas (then VISI) proposed to organize systematic meetings. The Rector of Technische Hochschule Leipzig (THL), Prof. K. Fiedler, approved the initiative. The collection of papers from the first Colloquium was published in the first joint publication (Fiedler et al., 1986). The team grew dynamically, but its core consisted of three centers: Leipzig University of Applied Sciences (Germany), Vilnius Gediminas Technical University (Lithuania) and Poznań University of Technology (Poland).

Apart from their authority and reliability in conducting research, the three centers contributed to this "alliance" with the following scientific achievements. From the German side, first of all, the development and applications of game theory; from the Lithuanian side multiple criteria methods, and from the Polish side - balancing construction processes under stochastic conditions by appliyng the theory of queue and the theory of reliability.

This form of cooperation resulted not only from the need to exchange experiences and compare scientific achievements, but also made it possible to access a wider range of information, journals and books, which were available at the cooperating centers. It also created the possibility of publishing the results of scientific works in journals in Germany, Lithuania and Poland. Moreover, the cooperation created a platform where doctoral and postdoctoral dissertations could be consulted, and professors from individual centers were and still are invited to review research papers. The knowledge and combined efforts of three academic centers created a synergy that gave rise to many original methods and spectacular implementations.

In terms of numbers, all this made the achievements impressive. Several hundred articles and dozens of books can be mentioned. An attempt to quantify the achievements of the first 25 years is presented in the works of Tamošaitienè et al. (2010) and Vilutienè and Tamošaitienè (2011). According to them, the cooperation gave very good results: 41 scientific books have been written, including seven scientific monographs; more than four hundred articles have been published in scientific journals; 13 professors defended their habilitations or successfully passed the habilitation procedure; 54 doctoral students defended their doctoral dissertations in the area of civil engineering.

Today it is almost impossible to quantify the research output; it counts in the hundreds. In addition, it is not known whether it is the effect of the Colloquia or the work of the ORSDCE group; or whether it was part of routine duties of an employee at the home university.

The cooperation was carried out in the spirit of integral humanism. It continues with no xenophobic attitudes. Good scientific cooperation and a good atmosphere allowed for peaceful development, regardless of the serious political upheavals accompanying these meetings. What should be mentioned here is the collapse of the USSR, the independence of Lithuania, the merger of two German states, the division of Czechoslovakia, Poland's accession to NATO. The influence of these events could be felt during the $8^{\text {th }}$ Colloquium in Vilnius (2001). The collapse of the political systems and changes in the economic system had no negative impact on the level of cooperation. It gave a new impetus to the application of theory in practice, first of all, the scope of topics increased with added macro-economic issues. The motto of the cooperation was "Sapere Aude" (Horace) with Prof. E. K. Zavadskas in the forefront who is regarded as the Godfather of the Colloquia. 


\section{A new form of cooperation - EURO Working Group ORSDCE}

With time, the existing organizational form proved insufficient. Moreover, the range of research topics expanded significantly. The research areas had been limited mainly to operational research in construction. Then, prof. E. K. Zavadskas suggested giving priority to the subject of the analysis of operational research in construction in the context of sustainable development.

The idea of the new direction of research arose from the understanding that there was a lack of a comprehensive approach and a synthesis of models linking different tasks, whereas sustainability priorities combine crosscutting issues of environment protection, energy efficiency, optimization of mobility and technology penetration, with solutions involving different levels of governing institutions and groups pursuing various goals.

Following the launch of a new research area, it was proposed to set up a EURO ${ }^{1}$ Working Group on Operational Research for Sustainable Development and Civil Engineering (ORSDCE). This proposal was discussed at the 12th Colloquium and a decision was taken to submit an application to the EURO Executive Committee during the regular EURO Conference. At the 23rd European Operations Research Conference, the EURO Executive Committee considered the proposal prepared by the Steering Group, approved the establishment of a new EURO Working Group and awarded it the EURO label. In this way, the group was granted membership of the European Association of Operations Research Societies and received related rights and obligations.

Now 33 of EURO Working Groups exist in the organizational network of the Association of European Operational Research Societies. These working groups are a significant part of the EURO.

Why was the topic of Operations Research for Sustainable Development and Civil Engineering chosen? Primarily, because the past and present activities of the group members are related to these issues. The results of research in this area are impressive, highly valued by the international scientific community, and need to be developed further. In addition, the research areas of previously established EURO working groups did not cover the topics of sustainable development and civil engineering, although the importance and necessity of applying operational research methods in these areas do not raise doubts. The application of operations research methods in the areas of sustainable development and civil engineering is significant in resolving conflicts between various stakeholders. Operations research methods can serve as a sustainable tool for economic prosperity, build environment quality, social justice and technology efficiency. In emphasizing the above issues, the members of the working group set the following goals:

- to facilitate the collaboration between European researchers working in the areas of civil engineering and sustainable development;

- to develop and apply multi-criteria approaches to sustainable development and civil engineering;

- to promote innovation based on the application of multi-criteria methods in the construction industry;

\footnotetext{
${ }^{1}$ EURO is the "Association of European Operational Research Societies" within IFORS, the "International Federation of Operational Research Societies", http://www.euro-online.org/
} 
- to ensure the continuity and progress of work and convey to scientific communities the ideas of multi-criteria decision-making, the results of the research, thoughts and critical discussions of group members through annual meetings and conferences.

The emergence of the EURO Working Group on Operational Research for Sustainable Development and Civil Engineering resulted from more than 20 years of cooperation between research institutions in three European countries (Germany, Poland and Lithuania). During this period, more than a hundred scientists from different parts of the world participated in and joined the EURO working group EWG-ORSDCE organized by EWG. The group currently has more than 100 members from 20 countries (Lithuania, Germany, Poland, United Kingdom, Belgium, Denmark, the Netherlands, Portugal, Latvia, Estonia, the Czech Republic, Slovenia, Romania, Peru, Mexico, Russia, Ukraine, Australia, Iran, Spain, Chile and the USA) (Figure 2).

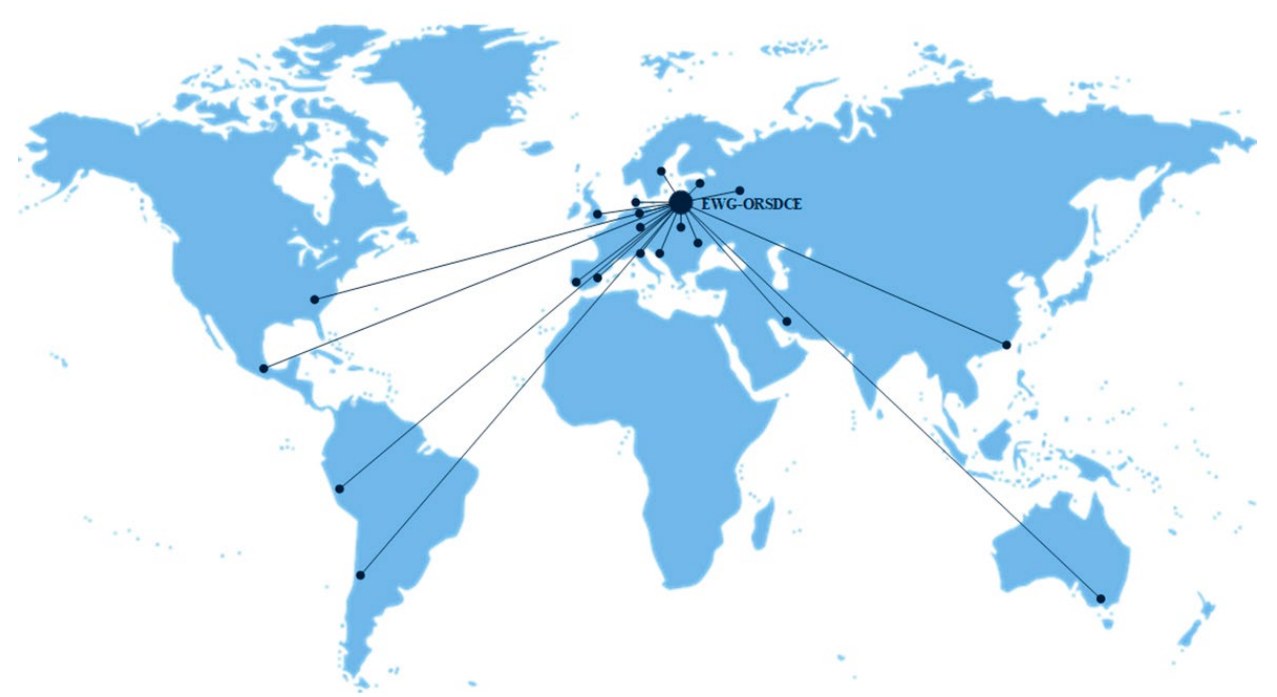

Figure 2. The cooperation networks of EWG ORSDCE

\section{Multidimensional character of research topics}

Not only the scope of international cooperation (initially, in the "triangle") was gradually expanding, but also the subject matter itself was developing dynamically. Figure 3 presents the fundamental aspects characterizing this development, including the determining conditions, research and discussion topics, economic and engineering implementations.

The participants realized that theoretical and practical achievements depended on technology, design and legislative conditions affecting all levels of consideration: from macro to micro (the largest field in Figure 3). This meant the need to look at the scope of our work both from a vertical and horizontal perspective.

The subject matter of the first Colloquia was limited to the MICRO level (especially the construction processes), gradually entering the MESO area (first, the construction PROJECT, then the enterprise). Only after the political and economic transformations in our countries 
in the nineties, the field of research was expanded to the MACRO level. Consequently, the research area and topics are listed in the upper part of the right oval in Figure 3 appeared.

At the MICRO level, the triad consisting of construction - technology - labor consumption was followed. The labor intensity was a step to determine the time and cost of implementation. Another triad was also taken into account (due to apicality), namely efficiency - law money. This triad accompanied such issues as methods of financing investments, budgeting, life cycle and the economics of design.

The building life cycle mentioned above or, more precisely, Life Cycle Cost Analysis (LCCA), is the keystone that holds the issues of multidimensionality together, especially in the context of operating costs and the use of discounted cash flows (Net Present Value). Therefore, it is a temporal dimension or, to put it conventionally - a horizontal dimension. The vertical and horizontal dimensions were significantly strengthened by the problem of sustainable development and later by the influence of the ORSDCE group.

Further considerations on the multidimensionality and multi-application nature of the subject matter of the Colloquia are presented in two synthetic parts: theoretical (including research instruments, methods, phenomena), and practical (characteristic applications in engineering and economics).

\section{Research instruments, methods, phenomena}

When reviewing the phenomena and tools needed to solve research problems in the period of the Colloquia (and presented during the Colloquia), it can be stated that almost all of the listed in Figure 3 (middle oval) are suitable for solving problems present at all three MICRO, MESO and MACRO levels. The second observation points to the supremacy of multi-criteria decision-making tools, including "Multiple-criteria decision-making" (MCDM). Issues such as selection and varianting were valuable materials for MCDM use and development. The Vilnius Center already had significant achievements in the area at that time (Zavadskas, 1979, 1987, 1991). Due to the specificity of those years, all the works were published in Russian. We will begin our review with the MCDM methods.

The team identifying with the Colloquium and the ORSDCE has been constantly working on creating new MCDM methods and modifying the existing ones. During the 30 years of scientific cooperation, the members of EWG ORSDCE have created methods for decision support, e.g. COPRAS, MOORA, MULTIMOORA, WASPAS, ARAS, SWARA, KEMIRA, MAMVA, COPRAS-G, COPRAS-F, COPRAS-IVIF, ARAS-F, ARAS-G. As of today, the team's account includes, among others the following methods (Figure 3).

The FARE (Factor Relationship) method (Ginevicius \& Podvezko, 2007) for determining the weights of a large number of criteria based on the relationship between one of them and the others. The SECA method (Keshavarz-Ghorabaee et al., 2018) for simultaneous evaluation of criteria and alternatives using the problem of multi-criteria nonlinear programming. Several methods for determining the weight of the criteria created. One of them is WEBIRA method (Krylovas et al., 2017) based on the strategy of balancing weighting. Another one is PIPRECIA method (Stanujkic et al., 2017a) for determining the criteria weight when the consensus among experts cannot be reached. KEMIRA method (Krylovas et al., 2014) based on a weighting strategy, three different metrics were used to calculate the median. 


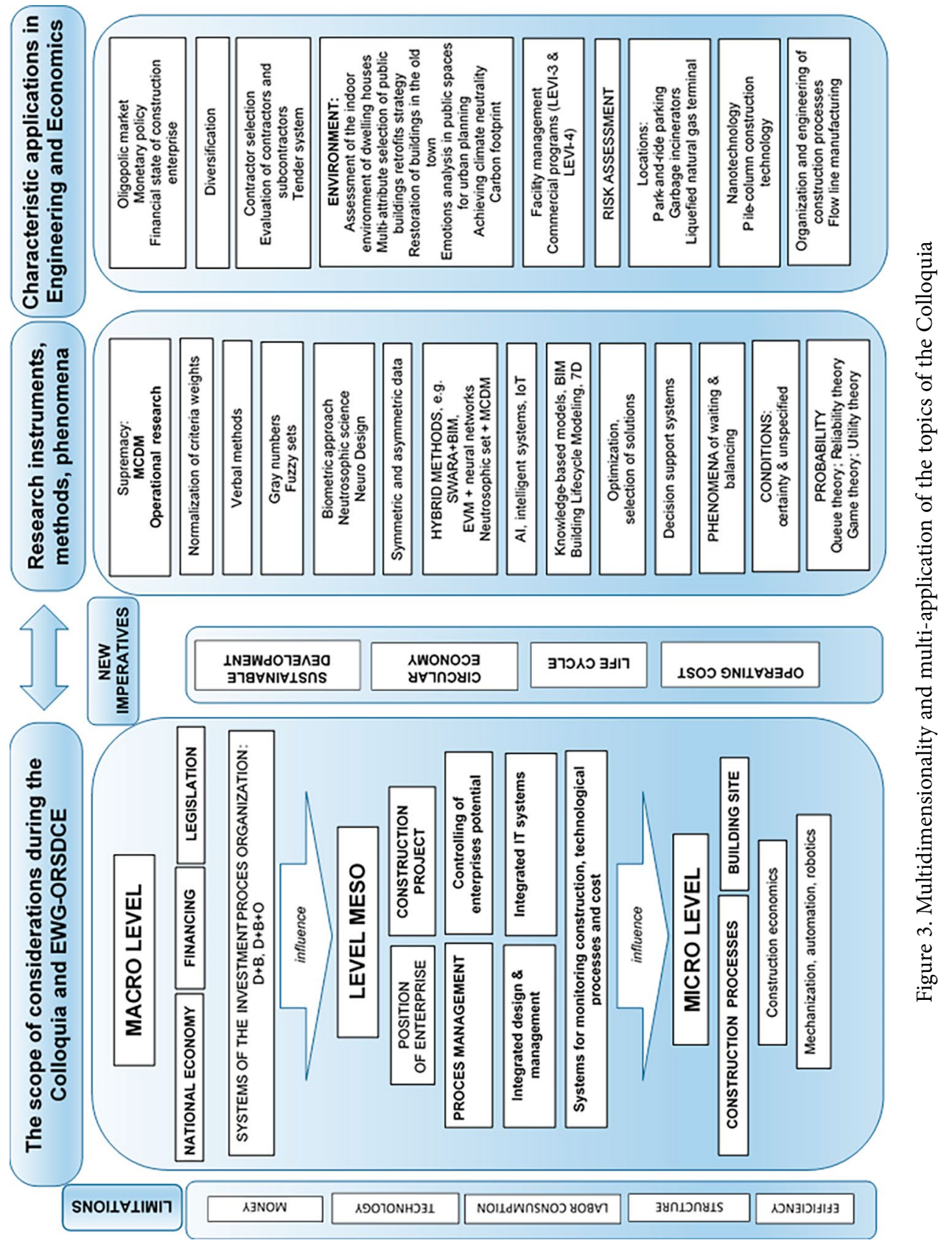


A special group of methods is those based on the properties of type T fuzzy sets, including EAMRIT-2F method (Keshavarz Ghorabaee et al., 2016a). The optimality characteristic of this method is based on the area under the lower and upper membership function graphs as well as the probability analysis of the fuzzy sets. AFRAW method (Keshavarz Ghorabaee et al., 2016b) based on the modeling in terms of interval T-2 fuzzy sets; integration of subjective data about weights of the criteria provided by experts with objective data about these weights.

Different approaches to be found in the methods: CODAS (simultaneous use of two Euclidian and Taxicab metrics), EDAS (allows selecting the best alternative based on the positive and negative deviations from the average solution), Modified WS-PLP (summing up the weights \& new normalization procedure), ARCAS (group decision making), COCOSO (combination of compromise decision-making strategies with some approaches to data aggregation).

In terms of methods of determining criteria weights, it is CILOS (the analysis of the criterion significance variability, considering changes in the significant value of other criteria), and IDOCRIW (using the best features of the entropy method).

Most of these methods were developed after 2014. Their names are most often acronyms, for instance, CODAS is COmbinative Distance-based ASsessment method, AFRAW is Assessment based on Fuzzy Ranking and Aggregated Weights, popular EDAS is Evaluation based on Distance from Average Solution, and COCOSO is COmbined COmpromise Solution. They have been published in such journals as Informatica, International Journal of Computers, Communications \& Control (IJCCC), Economic Computation and Economic Cybernetics Studies and Research (ECECSR), Studies in Informatics and Control, Journal of Business Economics and Management. For a review of these methods, see Bausys (2019), Keshavarz Ghorabaee et al. (2017), Mardani et al. (2018a, 2018b) and Kapliński et al. (2019).

Some very interesting results were obtained in terms of extension or modification of the MCDM methods. The hybrid effect was obtained by compiling some methods, considering fuzzy or grey numbers, sometimes probabilities, methods of criteria and alternatives evaluation, and most of all, through normalization, including aggregation of weights. The list of these hybrid methods is abundant, and they have been published in various journals, e.g. Applied Mathematical Modeling, Soft Computing, Applied Soft Computing, Symmetry, Studies in Informatics and Control. The extended MCDM methods include Rough ARAS, R-SWARA, EDAS-I2FS, Entropy-KEMIRA, Neutrosophic-MAMWA, G-EDAS, F-CODAS, G-OCRA, Stochatic EDAS, Neutrosophic MULTIMOORA, Intuitionistic fuzzy EDAS, WASPAS-I2FS, F-EDAS, WASPAS-SVNS, F-WASPAS, VIKOR-INS, COPRAS-SVNS, ELECTREIDAT, COPRAS-WIRN, Extended SWARA, ELECTRE III-IV IF, ELECTRE-IDAT. For a discussion of some of these methods, see Shen et al. (2018). The in-depth assessments of these methods presented in the following works describing: MULTIMOORA method (Baležentis \& Baležentis, 2014; Hafezalkotob et al., 2019), COPRAS method (Stefano et al., 2015), SWARA and WASPAS (Mardani et al., 2017b) SMARA and SMART with their application (Nakhaei et al., 2016).

An example of the development and extension of some approaches is the improvement of the VIKOR method. It has recently become very popular in applications. 
The VIKOR method (Opricovic, 1998) determines the compromise ranking list and the compromise solution obtained with the initial (given) weights. Generally, this method focuses on ranking and selecting from a set of alternatives in the presence of conflicting criteria. It has two interesting modifications, i.e. fuzzy aggregation operators and considering the neutrosophic set environment. The results have been given in the following works: Mardani et al. (2018a) and Bausys and Zavadskas (2015).

The supremacy of the MCDM results in the achievements of the team identifying with the Colloquia and the ORSDCE results not only from the number of methods and articles, but also from the fact that they are the most frequently quoted in the international literature.

An example of going beyond the circle of Civil Engineering and entering the field of health and psychology organization - including the issue of the neuro decision matrix and the COPRAS and ViNeRS methods - is, among others, the work by Kaklauskas et al. (2020a).

Where the problem areas were difficult to quantify, e.g. due to historical and architectural categories (values), it was proposed to use subjective assessments. Verbal Decision Analysis (VDA) was adopted and further developed. The method was developed thanks to cooperation with colleagues from Moscow, O.I. Larichev and D.Yu. Kochin (Russian Academy of Sciences).

The most important feature of VDA, which distinguishes it from other well-known methodological approaches in decision-making theory, is the use of non-numeric (qualitative) information at all stages of the analysis. Using VDA problem solutions obtained without any transformation into the numerical form. Interesting applications have been found in medicine, psychology, architecture, and, above all, in investment evaluation. An example is (Ustinovičius \& Kochin, 2003) in the area of investment and risk determination. In the practice of organization and management, VDA methods have a significant advantage over axiomatic and heuristic methods.

In discussing the MCDM-Extensions above, we come across axioms that are better defined by neutrosophy. Neutrosophy, whose father is Smarandache F. (1998) looks at a proposition, a theory, an event, a concept, or an entity, in relation to its opposite. Thus, Neutrosophy reached the realm of multi-criteria decision-making methods. Our colleagues' experience shows that the MCDM methods have found their specific approach, i.e. Neutrosophic fuzzy sets. Here are examples of methods extended in this way: COPRAS (Bausys et al., 2015), WASPAS (Zavadskas et al., 2015), MULTIMOORA (Stanujkic et al., 2017b) and the hybrid result of COPRAS and ViNeRS Methods (Kaklauskas et al., 2020b). The Neutrosophic Science International Association has highly appreciated the above achievements.

Evidently, hybrid models play an important theoretical and practical role. A different, yet sophisticated hybrid approach has been developed with regard to potential buyers of green housing (AVABEPS) (Kaklauskas et al., 2020c). The research used neuromarketing and multicriteria examination of video advertisements for diverse client segments by applying neuro decision tables. It is an example of multi-discipline cooperation between the Faculty of Civil Engineering (VGTU, LT). Department of Computing (Imperial College London) and Cognitive Computing Group, Institute of Data Science and Digital Technologies (VU, LT).

It is also worth noting the use of MCDM in Building Information Modelling (BIM). In Khalesi et al. (2020) the Step-wise Weight Assessment Ratio Analysis (SWARA) method 
and BIM technologies have been combined to identify and reduce time delays caused by reworks in construction projects. The bibliometric approach in this respect is represented by Vilutiene et al. (2019). Other achievements in the area of BIM are presented in Saoud et al. (2017), Sarvari et al. (2020), Shkundalov and Vilutienė (2021), Ustinovichius et al. (2018), Ustinovičius et al. (2015), Vilutienè et al. (2020b, 2021), Zhang et al. (2016).

A solution to the symmetry or asymmetry of different data types can also be found in the hybrid approach. An example is Zavadskas et al. (2021a). The authors proposed different solution models, mainly covering uncertain data in multi-criteria decision-making problems as complex tools to balance the symmetry between goals, risks and constraints to cope with the complicated problems in engineering or management.

Rapid technical development forced interest in such topics as integrated management and design, BIM, 3D to 7D models, the Internet of Things (IoT), and Knowledge-Based Systems (KBS). There has been an abundance of publications in this area in the last decade. Let us mention one of them: Pishdar et al. (2018). This is IoT in supply chain management and a more precise evaluation of IoT application challenges based on the rough DEMATEL group.

Some works highlighted intelligent building systems (Antucheviciene et al., 2015), intelligent and biometric systems (Kapliński \& Tupenaite, 2011), information management in conditions of inadequacy (Antucheviciene et al., 2017). A critique of the information structure, insufficient from the point of view of sustainable development provided by Turskis et al., 2019c). Crowd biometrics analyzed by Kaklauskas et al. (2019c). INVAR method in the area of neuromarketing presented by Kaklauskas et al. (2019a).

Artificial intelligence (AI) techniques, including in particular Intelligent Decision Support Systems (IDSSs), harmonize with the above-mentioned issues. Artificial intelligence techniques can be utilized in all the components of IDSSs, such as in the database, knowledge base, model base, user interface. Some of the topics related to AI techniques are biometric and intelligent decision making support described by Kaklauskas (2015). The research continued with development and integration of intelligence, voice stress analysis, and iris recognition technologies in construction; integration of intelligent decision support systems in the life cycle of the built environment (Kaklauskas, 2016). Later the VINERS Neuromarketing system that can determine the emotional, affective and physiological status of viewers, was developed by Kaklauskas et al., 2020a). Some other include: one-to-one neuromarketing (Zavadskas et al., 2019); Earned Value Management (EVM) technique (Baumann et al., 2014), and artificial neural networks (Balali et al., 2020).

The importance of knowledge management is emphasized by the works, among others: in business (Abu Adi et al., 2021), and design (Bonenberg \& Kapliński, 2018). Merging knowledge bases and "life-time" gave rise to expert systems. The synthesis of these works is presented in the book (Kapliński et al., 1995). It was the first book on the applications of expert systems in the construction industry in this part of Europe.

The research achievement dating from the period of the first Colloquium seems to be modest. It could not be presented earlier, though, there was no Internet. Moreover, access to international journals was limited. Most of the achievements were published in local journals (mainly at a given University). The availability of publishing in foreign journals was limited. The introduction of mainly Lithuanian journals to the SCOPUS and Web of Science (WoS) 
databases allowed a noticeable representation of the achievements. By using this opportunity, this representation was realized successfully in the last two decades.

Thus, the subject matter at the MICRO level was dominant at that time (Figure 3). From the scientific point of view, the following phenomena were in the focus: essentially waiting, balancing and equilibrium (Peldschus \& Zavadskas, 2012). The principle was adopted not to create phenomena, but to study and describe them. Operational Research dominated as tools, among them the Queue Theory, (Kapliński, 1978), Reliability Theory (Kapliński \& Miłosz, 1996), Game Theory (Meszek, 2007; Peldschus, 2008), and Utility Theory. The review of works in the area of game theory was presented by (Kapliński \& Tamošaitiene, 2010; Peldschus, 2009, 2018). Fuzzy sets were introduced at the turn of the 20th and 21 st centuries. The Theory of Rational Decisions was the scientific foundation of our Colloquia.

The book (Zavadskas, 1987) was one of the first books dating from this period - an important introduction to later MCDM methods. The book synthesizing the achievements of MCDM (Zavadskas et al., 1994) was also important. In Poland, the first major publication (apart from network planning) was a book on the balancing of construction processes (Kapliński, 1978). Later, scoring methods developed (Kapliński, 2008), integrated management and flexible management (Pasławski, 2008), as well as the use of prospect theory (Zavadskas et al., 2016), and rough sets theory (Mardani et al., 2017a), completing the MESO level.

\section{Characteristic applications in engineering and economics}

The last column (in the right oval in Figure 3) shows some characteristic examples of theoretical research implementation. The range of issues is exceptionally large and is closely related to the three levels of debate during the Colloquia, the profile of research in home research centers, and then within the ORSDCE group.

The list of MICRO achievements is primarily related to the conditions set out on the left side of Figure 3 and is related to what these three centers contributed to the first Colloquia. In general, the issues concerned the organization and engineering of construction processes, the organization of the construction site, monolithic construction, and such detailed issues as the use of the flow line method (e.g. in stochastic conditions). Optimization in a broad sense was treated on an equal footing with the use of mathematical methods. Examples of the achievements of this level and the early period are presented, among others, in Fiedler et al. (1986), Kapliński (1978, 1997).

MACRO level works (compared to the MICRO level ones) have a contrasting range. The proliferation of these works could be observed after 2000. The first works in this area focused on diversification of the production program (Ginevičius, 1998), later they entered the area of the financial state of construction enterprises, even the oligopolic market. The research presented in Ginevičius et al. (2010) may be an example.

This group includes socio-economic topics (as systems), including SEA (Kapliński \& Peldschus, 2011): strategic environmental assessment; also the selection of the optimal real estate investment; the European Union in a transition economy; and quantitative evaluation of social phenomena (Nazarko \& Chodakowska, 2015; Nazarko \& Kononiuk, 2013; 
Radziszewski et al., 2016). Housing issues (sustainable affordable housing) were also debated by Maliene et al. (2018), Mulliner et al. (2013, 2016). More humanistic issues, including pay and unemployment, can be found in Melnikas (2018), Ozturk et al. (2019).

Economic issues at the MAKRO level also constitute an excellent platform for the utilization of MCDM and operational research. A broad overview of such applications can be found in the article (Zavadskas \& Turskis, 2011), which aroused great interest and has already been cited 414 times (SCOPUS database). The later period is summarized in (Zavadskas et al., 2014).

Economic changes resulted in discussions on several variants of the organization of the investment process, including the organization of tenders. Several works were created to evaluate contractors. Some of them are Jaskowski et al. (2010), Turskis (2008), Zavadskas et al. (2009). The organization of the investment process was analyzed, for example, as Design and Build system (Lesniak et al., 2012), sustainable construction management (Erdogan et al., 2019). The supplier selection in the light of the CoCoSo-G method is presented in (Yazdani et al., 2019), and in the light of fuzzy sets in (Keshavarz Ghorabaee et al., 2017).

The selection of a contractor is one of the most important decisions made by the owner of a construction site. A number of works have been created, e.g. selection based on the method of multicriteria complex proportional assessment (Zavadskas et al., 2009), a model based on the theory of fuzzy sets, also including computer software applications (Plebankiewicz, 2010). A more sophisticated approach, i.e. compiling dynamic fuzzy and MCDM (EDAS method), is presented in (Keshavarz Ghorabaee et al., 2018).

For years, localization problems have been both a satisfactory and practical area of research. Figure 3 lists only a few examples regarding park-and-ride parking, garbage incinerators, liquefied natural gas terminal, location of new footbridges (combining multi-criteria task and GIS) (Zagorskas \& Turskis, 2020). All the examples mentioned above use MCDM methods and even hybrid approaches. The hybrid solution model proposed by Zavadskas et al. (2021b) for decision-making integrates four different methods and several fuzzy criteria values. And so, an example of the selection of location for a liquefied natural gas terminal (Bausys et al., 2015) presents the multicriteria decision-making method with single value neutrosophic sets (SVNS). The proposed approach consists of the following steps: neutrosophication, MCDM solution using the neutrosophic sets operations, de-neutrosophication. It is worth noting that in the period of the first Colloquia, for solving location optimization problems mainly models based on linear programming or dynamic programming were used.

The more extensive was the use of decision support methods, the stronger was the need for standardization (usability, weights, criteria) (Brauers, 2007a, 2007b; Zavadskas et al., 2003). Of course, the criteria can be qualitative and quantitative. They usually employ different units of measurement and differ in optimization direction. In this case, the normalization aims at obtaining comparable scales of criteria values. Having joined forces, a package of commercial programs called LEVI-3.0 was developed. It was the result of the cooperation between the VGTU and HTWK (Peldschus, 2008; Zavadskas et al., 2002).

The next version of the LEVI-4.0 program was modified for evaluating various processes in economics, engineering, and management (Turskis et al., 2009). The packages include decision-making matrix, Game theory methods, linear transformation; multiple criteria evalu- 
ation; non-linear transformation; one-sided and two-sided problems. Based on the research carried out it turned out, inter alia, that the logarithmic normalization of the decision matrix gave the most stable results in solving multi-criteria decision problems. Research in the area of standardization is still ongoing, an example may be Liao et al. (2020), which takes into account the Double Normalization-based Multi-Aggregation (DNMA) method.

Risk assessment of construction processes and projects has been a rewarding area for research and applications since the beginning of the Colloquia. The first works were based solely on the theory of probability: the theory of reliability was the main research instrument. Spectacular achievements were also noted thanks to the application of queue theory. In this manner, time or material reserves were determined. The analyses were supported by a digital simulation; a classic example is the article (Kapliński \& Miłosz, 1996). A summary of the research from this period in the relationship of Reliability - Risk Management - Contingency is to be found in Turskis et al. (2012).

Because we deal with risk every day, therefore our achievements include works, e.g. on financial risk (Dziadosz et al., 2015), time and costs risks (Plebankiewicz et al., 2020), or job security, in fuzzy numbers (Mohandes et al., 2020).

The issue of risk assessment was given a new impetus when the MCDM methods were employed. Here are some examples. Shevchenko et al. (2008) presents a method of multiattribute comparative analysis (combining CLARA and SAW methods) of variants of investment classified risks in construction. However, in Zavadskas et al. (2010) the risk evaluation attributes are selected taking into consideration the interests and goals of the stakeholders as well as factors that influence the construction process efficiency and real estate value. The ranking of objects and determination of their optimality is determined by applying TOPSISgrey and COPRAS-G methods with attribute values determined at intervals. The use of the DEMATEL-fuzzy and ANP methods in interrelations among risk factors is presented by Hatefi and Tamošaitiené (2019). Asadi et al. (2018) taking an oil company as an example, assessed risk based on the Elena guideline. A Delphi study using the TOPSIS method is presented by Tamošaitiené et al. (2021a). Ghodoosi et al. (2021) proposed practical quantitative approach based on reliability analysis, which enables estimators assessing bid risk allocation and making bid/no-bid decisions based on estimating the probabilities of schedule and cost overruns.

Intriguing results can be obtained at the interface between Facility Management and AI. Digitization plays an important role in a broadly conceived area of management (control). It was especially clear during the Kołobrzeg Colloquium in 2007. The neuromarketing and BIM problems discussed above are characteristic examples of that statement. The subject area has potential. The review article (Nikmehr et al., 2021) is significant. Digital models of construction designs, digital control models, models for assessing construction designs from the point of view of the client or developer, digital transformations - all those are often supported by Fuzzy Logic or MCDM-fuzzy models (Gajzler \& Zima, 2017; Morkūnaité et al., 2019; Shkundalov \& Vilutienė, 2021; Tamošaitienė et al., 2021b). The smart subject matter with fuzzy cognitive maps is presented by Miguel et al. (2019). The hybrid differential evolution online sequential extreme learning machine (DE-OSELM) model was applied by Bielskus et al. (2020) for building occupants' presence prediction in an open-space office. 
In recent years, the presentations of design works became abundant. Here are some of them.

- Forecasting the building's demand for thermal energy, considering the Complex Proportional Assessment Method (D’Amico et al., 2020);

- Designing green houses, considering neuromarketing (Kaklauskas et al., 2019d);

- Research and design of pedestrian zones (Dičiūnaitė-Rauktienè et al., 2018);

- Hybrid design on the example of airport runways (Turskis et al., 2019a);

- Design strategies considering the KANO two-dimensional quality model (Juan et al., 2014);

- Indication of "Best Places to Live" using COPRAS and VINERS methods (Kaklauskas et al., 2019b).

Practical applications of the MCDM methods presented in research of designing bicycle paths (Zagorskas \& Turskis, 2020), designing (selecting) building foundations (Turskis et al., 2016), optimizing steel structures (Turskis et al., 2019d), assessing the sustainability of alternative structural solutions of a building (Vilutienè et al., 2020a). Choice of materials for a dam construction analyzed by Maghsoodi et al. (2019). Road design solutions discussed in Brauers et al. (2008), Zavadskas et al. (2007). Building maintenance planning described by Al-Refaie et al. (2020). Project portfolio selection in uncertainty conditions was analyzed in Mohagheghi et al. (2019). Dilemmas on the border between engineering and architecture were presented (Bonenberg \& Kapliński, 2018; Kapliński \& Bonenberg, 2020).

Earlier works focused, inter alia, on research on labor consumption of flexible corrugated steel structures assembly (Janusz \& Kapliński, 2006), evaluation of structural building systems (Kapliński \& Thiel, 1995), the economic choice (ELECTRE-III) of a museum heating system (Thiel \& Mroz, 2001). Work protection and safety also have their solutions (Mohandes et al., 2020; Skibniewski, 2014; Turskis et al., 2019b).

In this short overview of achievements, it is worth presenting examples of important environmental implementations. As part of the Colloquium, and later as part of the ORSDCE, the issues of the internal and external environment of the building were debated. It most often concerned dwelling houses, retrofit and renovation of residential districts, in particular in historic parts of cities, protected areas and priority conservation protection areas. The subject of these works moved dynamically towards sustainable construction (Zavadskas et al., 2018). Here are some characteristic examples. A monograph on intelligent decision support systems in the life cycle of the built environment, i.e. urban development and infrastructure, was written by Kaklauskas (2016). The decision model for selection of optimal combinations of modernization measures presented by Rasiulis et al. (2016). The study of Vilutiene and Ignatavičius (2018) presents the key performance indicators for quality monitoring of sustainable renovation. Tamosaitiene (2018) discussed on the risk vs. agile built environment relationship. A different outlook on the above-mentioned issues, i.e. through emotions, presented in (Kaklauskas et al., 2020a, 2021). Considerations in the field of circular economy presented by Stankevičienè and Nikanorova (2020). There are more such works, but all were supported by the research methods listed in Figure 3. 


\section{Echoes of collaboration and achievements}

The echoes of the Colloquia success meant that cross-border cooperation was set as a model, and the idea was expressed in the statements of four senates of Technical Universities in Poland (Warsaw, Gdańsk, Wrocław and Poznań) while supporting the application for awarding the title of Doctor Honoris Causa to professor E. K. Zavadskas. Similarly, Prof. Peldschus and Prof. Kapliński were honored in Vilnius.

Moreover, for invaluable contributions in promoting cooperation between Poland and Lithuania, prof. E. K. Zavadskas was awarded the "Two Nations Award" (2004) by the Presidium of the Deputies' Assembly of the Seym of the Republic of Poland and the Seimas of the Republic of Lithuania.

The collaboration and all previous Colloquia have been and are conducted in the spirit of integral humanism. It was noticed by the Polish magazine "Lithuania" and a Lithuanian magazine "Kulturos barai" which awarded the "Integral Humanism" medals to two Professors: E .K. Zavadskas and O. Kapliński.

There are numerous examples of the impact of the research work of the Vilnius center in the area of multi-criteria approach on other centers abroad. The book (Alinezhad \& Khalili, 2019) can be one example. The authors, researchers at Islamic Azad University Qazvin, Iran, present 27 methods of the Multiple Attribute Decision Making (MADM). In almost all chapters, the authors refer to the achievements of the participants of the Colloquia where these methods were presented. They pay attention to both theoretical and implementation achievements.

The assessment of our Colloquia colleagues and ORSDCE members' achievements given by the scientists from the Business School, Sichuan University, China (Liu \& Xu, 2021) is also significant. Their article reviews the studies on the ARAS method from the perspectives of basic information (including the bibliometrics analyses and the outline of ARAS method), the development of the theory (including the development of MADM mechanism, different information environments and combination with different methods), the development on the application and the future challenges. The contribution of our colleagues (a dozen of academics) to the development of this method (the additive ratio assessment system) is highlighted.

The authors, active participants of the Colloquilia and ORSDCE, mainly from VGTU, have been regularly awarded since 2006 by ScienceWatch.com and Essential Science Indicators $^{\mathrm{TM}}$ of Thomson Reuters for the greatest percentage increase of citations. For example, in 2009, three works were distinguished into three categories:

- as New Hot Papers in the area of Engineering, the paper by Zavadskas et al. (2008),

- in the area of Economics \& Business, the paper by (Ginevičius et al., 2008),

- as Fast Breaking Paper in the area of Economics and Business, the paper prepared by Turskis (2008).

Stanford University, together with the publishing house Elsevier and SciTech Strategies, has created a ranking of $2 \%$ of the best scientists in the world. 159,648 names were checked.

The dataset in version 2 (Baas et al., 2020) is based on the Scopus database as of May 6, 2020 , and also includes the $2 \%$ best for each domain. In addition, in the area of Civil Engineering prof. E. K. Zavadskas achieved a very high position: number 13. Our colleagues from VGTU are also on the list: Z. Turskis, A. Kaklauskas, J. Antucheviciene, H. Sivilevičius and 
L. Ustinovichius (positions from 86 to 763). Five of these researchers work on the development of decision-making methods. These methods are widely used not only in the listed areas of Civil Engineering but also in other areas of science. That is why they are on the list of the most cited scientists. It confirms the earlier observation made by us when we discussed the genesis of international cooperation in the Lithuania - Germany - Poland triangle, namely that science is not divisible, the methods are the same but the applications differ.

Even greater recognition came from Web of Science ${ }^{\mathrm{Tw}}$. This institution, in its report entitled Highly Cited Researchers, analyses and presents pioneers in their respective fields over the last decade, based on the production of multiple highly-cited papers that rank in the top $1 \%$ by citations for area and year (Clarivate, 2020). Two scholars are mentioned among the participants of the Colloquia and members of the WG ORSDCE. Prof. E. K. Zavadskas is listed in two categories: "Economics and Business" and "Engineering", while Prof. Z. Turskis is listed in the "Cross-Field" category. According to Web of Science ${ }^{\mathrm{Tm}}$, of the world scientists and social scientists, Clarivate ${ }^{\mathrm{m}}$ Highly Cited Researchers truly are one in the 1,000. The analyses are powered by Web of Science Group's Essential Science Indicators. It is also splendor for their associates.

\section{Conclusions}

We are celebrating the 35th anniversary of the implementation of the idea, which, in this case, has become almost an "institution" and functioned under the name of the Colloquia. The cooperation initiated by three academic centers from Lithuania, Germany and Poland has tangible achievements and gained national and international recognition. It had a significant influence on the promotion of academic staff in our countries and abroad.

The initiation of the Colloquia in 1986 was preceded by earlier contacts (conferences, research internships, first joint publications), which proves a 40 -year-long reliable collaboration. The collaboration was carried out in the spirit of integral humanism. It continues with no xenophobic attitudes.

During this period, the scope of research evolved and the operating conditions changed. The organizational form has also changed, as there was a need to operate in a more formalized structure which materialized in joining the "Operations Research in Sustainable Development and Civil Engineering” EURO Working Group. The group associated with the Colloquia is the core of WG ORSDCE. The dominant center in this cross-border triangle has been and still is the Vilnius center.

Changing the formula to a more formalized one has positive aspects. It integrated the environment even more, and the implementation of research accelerated. Combining Operation Research with Sustainable Development produces spectacular results, as it provided an extra impetus towards new applications.

The presented review also presents the latest scientific achievements, i.e. selected publications from 2020 and 2021. This indicates the continuity of research despite the impressive jubilee. There is no stagnation. There is a phenomenal increasein the number of publications, and the growth is exponential. At the same time, the importance of teamwork has increased, often involving many people. 
The review of the achievements of 35-year-old Colloquia (in the area of research methods and implementation) shows clear supremacy of multi-criteria decision-making tools, including "Multiple-criteria decision-making". MCDM methods are powerful and flexible techniques for solving many problems related to sustainable development. They are also a satisfactory instrument for solving problems both at the micro and macro level, especially in terms of organization, management, and economics, considering cost optimization criteria. The development of the range of research has clearly marked the path to meeting the imperative of sustainable development, i.e. through the operating cost and the life cycle.

The cooperation always took place with the times. After the political and economic transformations, the cooperation has not stopped though the conditions have changed. The idea of the Colloquia (within the EURO Working Group) is now in the hands of young people and should be addressed to them. It should be their platform.

\section{Author contributions}

O.K. and T.V. conceived the study and were responsible for the design and development of the data analysis. O.K. and T.V. were responsible for data collection, analysis and interpretation. O.K. wrote the first draft of the article, T.V. performed review and editing, formatted the list of resources. All authors have read and agreed to the published version of the manuscript.

\section{Disclosure statement}

The authors declare no conflict of interest.

\section{References}

Abu Adi, W., Hiyassat, M., \& Lepkova, N. (2021). Business strategy development model for applying knowledge management in construction. Journal of Civil Engineering and Management, 27(4), 246-259. https://doi.org/10.3846/jcem.2021.14651

Al-Refaie, A., Al-Shalaldeh, H., \& Lepkova, N. (2020). Proposed procedure for optimal maintenance scheduling under emergent failures. Journal of Civil Engineering and Management, 26(4), 396-409. https://doi.org/10.3846/jcem.2020.12315

Alinezhad, A., \& Khalili, J. (2019). New methods and applications in Multiple Attribute Decision Making (MADM). Springer. https://doi.org/10.1007/978-3-030-15009-9

Antucheviciene, J., Kala, Z., Marzouk, M., \& Vaidogas, E. R. (2015). Solving civil engineering problems by means of fuzzy and stochastic MCDM methods: Current state and future research. Mathematical Problems in Engineering, 2015, 362579. https://doi.org/10.1155/2015/362579

Antucheviciene, J., Tavana, M., Nilashi, M., \& Bausys, R. (2017). Managing information uncertainty and complexity in decision-making: editorial. Complexity, 2017, 1268980. https://doi.org/10.1155/2017/1268980

Asadi, P., Rezaeian Zeidi, J., Mojibi, T., Yazdani-Chamzini, A., \& Tamošaitienè, J. (2018). Project risk evaluation by using a new fuzzy model based on ELENA guideline. Journal of Civil Engineering and Management, 24(4), 284-300. https://doi.org/10.3846/jcem.2018.3070

Baas, J., Boyack, K., \& Ioannidis, J. P. A. (2020). Data for "Updated science-wide author databases of standardized citation indicators." Mendeley Data, V2.

https://elsevier.digitalcommonsdata.com/datasets/btchxktzyw/2 
Balali, A., Valipour, A., Antucheviciene, J., \& Šaparauskas, J. (2020). Improving the results of the earned value management technique using artificial neural networks in construction projects. Symmetry, 12(10), 1745. https://doi.org/10.3390/sym12101745

Baležentis, T., \& Baležentis, A. (2014). A survey on development and applications of the multi-criteria decision making method MULTIMOORA. Journal of Multi-Criteria Decision Analysis, 21(3-4), 209-222. https://doi.org/10.1002/mcda.1501

Baumann, T., Dziadosz, A., Kapliński, O., \& Rejment, M. (2014). Range of application and limitations of the Earned Value Methods in construction project estimation. Technical Transactions-Czasopismo Techniczne, 2-B, 65-72. https://doi.org/10.4467/2353737XCT.14.113.2563

Bausys, R. (2019). Mokslinių pasiekimų puokštè. In O. Binkyte-Vèliene, A., Jursaite (Eds.), Neprarastu dienu metai. Akademikas Edmundas Kazimieras Zavadskas. II dalis. (pp. 76-86). Technika. https://doi.org/10.20334/2019-011-P

Bausys, R., \& Zavadskas, E. K. (2015). Multicriteria decision making approach by VIKOR under interval neutrosophic set environment. Economic Computation and Economic Cybernetics Studies and Research (ECECSR), 49(4), 33-48.

Bausys, R., Zavadskas, E. K., \& Kaklauskas, A. (2015). Application of neutrosophic set to multicriteria decision making by COPRAS. Economic Computation and Economic Cybernetics Studies and Research (ECECSR), 49(2), 91-106.

Bielskus, J., Motuziene, V., Vilutienè, T., \& Indriulionis, A. (2020). Occupancy prediction using differential evolution online sequential Extreme Learning Machine model. Energies, 13(15), 4033. https://doi.org/10.3390/en13154033

Bonenberg, W., \& Kapliński, O. (2018). The architect and the paradigms of sustainable development: A review of dilemmas. Procedia Engineering, 10(1), 100. https://doi.org/10.3390/su10010100

Brauers, W. K. M. (2007a). Normalisation in multiobjective optimisation: A general overview. International Journal of Management and Decision Making, 8(5-6), 461-474. https://doi.org/10.1504/IJMDM.2007.013412

Brauers, W. K. M. (2007b). What is meant by normalisation in decision making? International Journal of Management and Decision Making, 8(5-6), 445-460. https://doi.org/10.1504/IJMDM.2007.013411

Brauers, W. K. M., Zavadskas, E. K., Peldschus, F., \& Turskis, Z. (2008). Multi-objective decision-making for road design. Transport, 23(3), 183-193. https://doi.org/10.3846/1648-4142.2008.23.183-193

Clarivate. (2020). Highly cited researchers. Web of Science ${ }^{\mathrm{TM}}$. Retrieved October 8, 2021, from https://recognition.webofscience.com/awards/highly-cited/2020/

D’Amico, A., Ciulla, G., Tupenaite, L., \& Kaklauskas, A. (2020). Multiple criteria assessment of methods for forecasting building thermal energy demand. Energy and Buildings, 224, 11022. https://doi.org/10.1016/j.enbuild.2020.110220

Dičiūnaitė-Rauktienè, R., Gurskienè, V., Burinskienė, M., \& Malienė, V. (2018). The usage and perception of pedestrian zones in Lithuanian cities: multiple criteria and comparative analysis. Sustainability, 10(3), 818. https://doi.org/10.3390/su10030818

Dziadosz, A., Tomczyk, A., \& Kapliński, O. (2015). Financial risk estimation in construction contracts. Procedia Engineering, 122, 120-128. https://doi.org/10.1016/j.proeng.2015.10.015

Erdogan, S. A., Šaparauskas, J., \& Turskis, Z. (2019). A multi-criteria decision-making model to choose the best option for sustainable construction management. Sustainability, 11(8), 2239. https://doi.org/10.3390/su11082239

Fiedler, K., Peldschus, F., \& Zavadskas, E. K. (1986). Methoden der Bautechnologischen Entscheidung. Wissenschaftliche Berichte Der Technischen Hochschule Leipzig.

Gajzler, M., \& Zima, K. (2017). Evaluation of planned construction projects using fuzzy logic. International Journal of Civil Engineering, 15(4), 641-652. https://doi.org/10.1007/s40999-017-0177-8 
Ghodoosi, F., Bagchi, A., Hosseini, M. R., Vilutienè, T., \& Zeynalian, M. (2021). Enhancement of bid decision-making in construction projects: A reliability analysis approach. Journal of Civil Engineering and Management, 27(3), 149-161. https://doi.org/10.3846/jcem.2021.14344

Ginevičius, R. (1998). Imoniu veiklos diversifikacija. Technika.

Ginevičius, R., Krivka, A., \& Simkunaite, J. (2010). İmonès konkurencines strategijos formavimo oligopolineje rinkoje modelis. Journal of Business Economics and Management, 11(3), 367-395. https://doi.org/10.3846/jbem.2010.18

Ginevicius, R., \& Podvezko, V. (2007, May 16-18). The influence of complex evaluation methods on rating the alternative solutions of wall insulation. In 9th International Conference: Modern Building Materials, Structures and Techniques (Vol. 1-3, pp. 248-251).

Ginevičius, R., Podvezko, V., \& Bruzge, Š. (2008). Evaluating the effect of state aid to business by multicriteria methods. Journal of Business Economics and Management, 9(3), 167-180.

https://doi.org/10.3846/1611-1699.2008.9.167-180

Hafezalkotob, A., Hafezalkotob, A., Liao, H., \& Herrera, F. (2019). An overview of MULTIMOORA for multi-criteria decision-making: Theory, developments, applications, and challenges. Information Fusion, 51, 145-177. https://doi.org/10.1016/j.inffus.2018.12.002

Hatefi, S. M., \& Tamošaitienè, J. (2019). An integrated fuzzy DEMATEL-fuzzy ANP model for evaluating construction projects by considering interrelationships among risk factors. Journal of Civil Engineering and Management, 25(2), 114-131. https://doi.org/10.3846/jcem.2019.8280

Janusz, L., \& Kapliński, O. (2006). The application of multifactor model LITCAC in the organization of assembly work of flexible corrugated steel structures. Technological and Economic Development of Economy, 12(3), 195-199. https://doi.org/10.3846/13928619.2006.9637741

Jaskowski, P., Biruk, S., \& Bucon, R. (2010). Assessing contractor selection criteria weights with fuzzy AHP method application in group decision environment. Automation in Construction, 19(2), 120 126. https://doi.org/10.1016/j.autcon.2009.12.014

Juan, Y.-K., Huang, S.-J. H., \& Chen, H.-T. (2014). Applying a Kano quality model for intelligent green building design strategies in Taiwan. International Journal of Strategic Property Management, 18(2), 125-137. https://doi.org/10.3846/1648715X.2014.893266

Kaklauskas, A. (2015). Biometric and Intelligent Decision Making Support. Springer. https://doi.org/10.1007/978-3-319-13659-2

Kaklauskas, A. (2016). Analysis of the life cycle of a built environment. Nova Science Publishers.

Kaklauskas, A., Abraham, A., Dzemyda, G., Raslanas, S., Seniut, M., Ubarte, I., Kurasova, O., BinkyteVeliene, A., \& Cerkauskas, J. (2020a). Emotional, affective and biometrical states analytics of a built environment. Engineering Applications of Artificial Intelligence, 91, 103621.

https://doi.org/10.1016/j.engappai.2020.103621

Kaklauskas, A., Bardauskiene, D., Cerkauskiene, R., Ubarte, I., Raslanas, S., Radvile, E., Kaklauskaite, U., \& Kaklauskiene, L. (2021). Emotions analysis in public spaces for urban planning. Land Use Policy, 107, 105458. https://doi.org/10.1016/j.landusepol.2021.105458

Kaklauskas, A., Bucinskas, V., \& Binkyte-Veliene, A. (2020b). The VINERS neuromarketing system. 2020 IEEE 10th International Conference on Intelligent Systems (IS), 345-351. https://doi.org/10.1109/IS48319.2020.9199948

Kaklauskas, A., Bucinskas, V., Vinogradova, I., Binkyte-Veliene, A., Ubarte, I., Skirmantas, D., \& Petric, L. (2019a). INVAR neuromarketing method and system. Studies in Informatics and Control, 28(3), 357-370. https://doi.org/10.24846/v28i3y201912

Kaklauskas, A., Dzitac, D., Sliogeriene, J., Lepkova, N., \& Vetloviene, I. (2019b). VINERS method for the multiple criteria analysis and neuromarketing of best places to live. International Journal of Computers, Communications and Control, 14(5), 629-646. https://doi.org/10.15837/ijccc.2019.5.3674 
Kaklauskas, A., Jokubauskas, D., Cerkauskas, J., Dzemyda, G., Ubarte, I., Skirmantas, D., Podviezko, A., \& Simkute, I. (2019c). Affective analytics of demonstration sites. Engineering Applications of Artificial Intelligence, 81, 346-372. https://doi.org/10.1016/j.engappai.2019.03.001

Kaklauskas, A., Ubarte, I., Kalibatas, D., Lill, I., Velykorusova, A., Volginas, P., Vinogradova, I., \& Milevicius, V. (2019d). A multisensory, green, and energy efficient housing neuromarketing method. Energies, 12(20), 3836. https://doi.org/10.3390/en12203836

Kaklauskas, A., Zavadskas, E. K., Schuller, B., Lepkova, N., Dzemyda, G., Sliogeriene, J., \& Kurasova, O. (2020c). Customized ViNeRs method for video neuro-advertising of green housing. International Journal of Environmental Research and Public Health, 17(7), 1-28. https://doi.org/10.3390/ijerph17072244

Kapliński, O. (1978). Harmonizacja cyklicznych procesów budowlanych w ujęciu stochastycznym [Harmonization of cyclical construction processes under stochastic conditions]. Poznan University Press.

Kapliński, O. (1997). Modelling of construction processes: A managerial approach (Studia z Zakresu Inżynierii No. 43). KILiW PAN, IPPT, Warsaw.

Kapliński, O. (2008). Usefulness and credibility of scoring methods in construction industry. Journal of Civil Engineering and Management, 14(1), 21-28. https://doi.org/10.3846/1392-3730.2008.14.21-28

Kapliński, O., \& Bonenberg, W. (2020). Architecture and engineering: the challenges - trends - achievements. Buildings, 10(10), 181. https://doi.org/10.3390/buildings10100181

Kapliński, O., \& Miłosz, M. (1996). Reliability of complex production systems. Civil Engineering Systems, 13(1), 61-73. https://doi.org/10.1080/02630259608970186

Kapliński, O., \& Peldschus, F. (2011). The problems of quantitative evaluation of socio-economic systems' development: Review. Inzinerine ekonomika-Engineering Economics, 22(4), 345-355. https://doi.org/10.5755/j01.ee.22.4.710

Kapliński, O., Peldschus, F., Nazarko, J., Kaklauskas, A., \& Baušys, R. (2019). MCDM, operational research and sustainable development in the trans-border Lithuanian-German-Polish co-operation. Engineering Management in Production and Services, 11(2), 7-18. https://doi.org/10.2478/emj-2019-0007

Kapliński, O., \& Tamošaitiene, J. (2010). Game theory applications in construction engineering and management. Technological and Economic Development of Economy, 16(2), 348-363. https://doi.org/10.3846/tede.2010.22

Kapliński, O., \& Thiel, T. (1995). Evaluation of multi-family housing systems in Poland. Construction Management and Economics, 13(4), 291-298. https://doi.org/10.1080/01446199500000034

Kapliński, O., \& Tupenaite, L. (2011). Review of the multiple criteria decision making methods, intelligent and biometric systems applied in modern construction economics. Transformations in Business \& Economics, 10(1), 166-181.

Kapliński, O., Zavadskas, E. K., Brzeziński, J., \& Kaklauskas, A. (1995). Expert systems in construction industry: trends, potentials and applications. Technika.

Keshavarz-Ghorabaee, M., Amiri, M., Zavadskas, E. K., Turskis, Z., \& Antucheviciene, J. (2018). Simultaneous evaluation of criteria and alternatives (SECA) for multi-criteria decision-making. Informatica, 29(2), 265-280. https://doi.org/10.15388/Informatica.2018.167

Keshavarz Ghorabaee, M., Amiri, M., Zavadskas, E. K., \& Antucheviciene, J. (2017). Supplier evaluation and selection in fuzzy environments: a review of MADM approaches. Economic Research-Ekonomska Istrazivanja, 30(1), 1073-1118. https://doi.org/10.1080/1331677X.2017.1314828

Keshavarz Ghorabaee, M., Amiri, M., Zavadskas, E. K., Turskis, Z., \& Antucheviciene, J. (2018). A dynamic fuzzy approach based on the EDAS method for multi-criteria subcontractor evaluation. Information, 9(3), 68. https://doi.org/10.3390/info9030068 
Keshavarz Ghorabaee, M., Zavadskas, E. K., Amiri, M., \& Antucheviciene, J. (2016a). Evaluation by an area-based method of ranking interval type-2 fuzzy sets (EAMRIT-2F) for multi-criteria group decision-making. Transformations in Business \& Economics, 15(3), 76-95.

Keshavarz Ghorabaee, M., Zavadskas, E. K., Amiri, M., \& Antuchevičienė, J. (2016b). A new method of assessment based on fuzzy ranking and aggregated weights (AFRAW) for MCDM problems under type-2 fuzzy environment. Economic Computation and Economic Cybernetics Studies and Research (ECECSR), 50(1), 39-68.

Khalesi, H., Balali, A., Valipour, A., Antucheviciene, J., Migilinskas, D., \& Zigmund, V. (2020). Application of hybrid SWARA-BIM in reducing reworks of building construction projects from the perspective of time. Sustainability, 12(21), 8927. https://doi.org/10.3390/su12218927

Krylovas, A., Kosareva, N., \& Zavadskas, E. K. (2017). WEBIRA - comparative analysis of weight balancing method. International Journal of Computers, Communications \& Control (IJCCC), 12(2), 238-253. https://doi.org/10.15837/ijccc.2017.2.2844

Krylovas, A., Zavadskas, E. K., Kosareva, N., \& Dadelo, S. (2014). New KEMIRA method for determining criteria priority and weights in solving MCDM problem. International Journal of Information Technology \& Decision Making, 13(6), 1119-1133. https://doi.org/10.1142/S0219622014500825

Lesniak, A., Plebankiewicz, E., \& Zima, K. (2012). Design and build procurement system - contractor selection. Archives of Civil Engineering, 58(4), 463-476. https://doi.org/10.2478/v.10169-012-0025-9

Liao, H., Ren, R., Antucheviciene, J., Šaparauskas, J., \& Al-Barakati, A. (2020). Sustainable construction supplier selection by a multiple criteria decision-making method with hesitant linguistic information. E\&M Ekonomie a Management, 23(4), 119-136. https://doi.org/10.15240/tul/001/2020-4-008

Liu, N., \& Xu, Z. (2021). An overview of ARAS method: theory development, application extension, and future challenge. International Journal of Intelligent Systems, 36(7), 3524-3565. https://doi.org/10.1002/int.22425

Maghsoodi, A. I., Maghsoodi, A. I., Poursoltan, P., Antuchevičienė, J., \& Turskis, Z. (2019). Dam construction material selection by implementing the integrated SWARA-CODAS approach with targetbased attributes. Archives of Civil and Mechanical Engineering, 19(4), 1194-1210. https://doi.org/10.1016/j.acme.2019.06.010

Maliene, V., Dixon-Gough, R., \& Malys, N. (2018). Dispersion of relative importance values contributes to the ranking uncertainty: sensitivity analysis of multiple criteria decision-making methods. Applied Soft Computing Journal, 67, 286-298. https://doi.org/10.1016/j.asoc.2018.03.003

Mardani, A., Jusoh, A., Halicka, K., Ejdys, J., Magruk, A., \& Ungku, U. N. (2018a). Determining the utility in management by using multi-criteria decision support tools: a review. Economic ResearchEkonomska Istrazivanja, 31(1), 1666-1716. https://doi.org/10.1080/1331677X.2018.1488600

Mardani, A., Nilashi, M., Antucheviciene, J., Tavana, M., Bausys, R., \& Ibrahim, O. (2017a). Recent fuzzy generalisations of rough sets theory: A systematic review and methodological critique of the literature. Complexity, 2017, 1608147. https://doi.org/10.1155/2017/1608147

Mardani, A., Nilashi, M., Zakuan, N., Loganathan, N., Soheilirad, S., Saman, M. Z. M., \& Ibrahim, O. (2017b). A systematic review and meta-analysis of SWARA and WASPAS methods: theory and applications with recent fuzzy developments. Applied Soft Computing, 57, 265-292. https://doi.org/10.1016/j.asoc.2017.03.045

Mardani, A., Nilashi, M., Zavadskas, E. K., Awang, S. R., Zare, H., \& Jamal, N. M. (2018b). Decision making methods based on fuzzy aggregation operators: three decades review from 1986 to 2017. International Journal of Information Technology \& Decision Making, 17(2), 391-466. https://doi.org/10.1142/S021962201830001X

Melnikas, B. (2018). The knowledge economy and the activation of scientific and technological progress: Contemporary challenges. Ekonomika, 97(1), 7-23. https://doi.org/10.15388/Ekon.2018.1.11775 
Meszek, W. (2007). Uncertainty phenomenon in property valuation. International Journal of Management and Decision Making, 8(5-6), 575-585. https://doi.org/10.1504/IJMDM.2007.013419

Miguel, B. P., Ferreira, F. A. F., Banaitis, A., Banaitienè, N., Meidute-Kavaliauskienè, I., \& Falcão, P. F. (2019). An expanded conceptualization of "Smart" cities: Adding value with fuzzy cognitive maps. E\&M Ekonomie a Management, 22(1), 4-21. https://doi.org/10.15240/tul/001/2019-1-001

Mohagheghi, V., Mousavi, S. M., Antuchevičiene, J., \& Mojtahedi, M. (2019). Project portfolio selection problems: a review of models, uncertainty approaches, solution techniques, and case studies. Technological and Economic Development of Economy, 25(6), 1380-1412. https://doi.org/10.3846/tede.2019.11410

Mohandes, S. R., Sadeghi, H., Mahdiyar, A., Durdyev, S., Banaitis, A., Yahya, K., \& Ismail, S. (2020). Assessing construction labours' safety level: A fuzzy MCDM approach. Journal of Civil Engineering and Management, 26(2), 175-188. https://doi.org/10.3846/jcem.2020.11926

Morkūnaite, Ž., Kalibatas, D., \& Kalibatienè, D. (2019). A bibliometric data analysis of multi-criteria decision making methods in heritage buildings. Journal of Civil Engineering and Management, 25(2), 76-99. https://doi.org/10.3846/jcem.2019.8315

Mulliner, E., Malys, N., \& Maliene, V. (2016). Comparative analysis of MCDM methods for the assessment of sustainable housing affordability. Omega, 59, 146-156.

https://doi.org/10.1016/j.omega.2015.05.013

Mulliner, E., Smallbone, K., \& Maliene, V. (2013). An assessment of sustainable housing affordability using a multiple criteria decision making method. Omega, 41(2), 270-279. https://doi.org/10.1016/j.omega.2012.05.002

Nakhaei, J., Lale Arefi, S., Bitarafan, M., \& Kapliński, O. (2016). Model for rapid assessment of vulnerability of office buildings to blast using SWARA and SMART methods (a case study of Swiss Re Tower). Journal of Civil Engineering and Management, 22(6), 831-843. https://doi.org/10.3846/13923730.2016.1189457

Nazarko, J., \& Chodakowska, E. (2015). Measuring productivity of construction industry in Europe with Data Envelopment Analysis. Procedia Engineering, 122, 204-212. https://doi.org/10.1016/j.proeng.2015.10.026

Nazarko, J., \& Kononiuk, A. (2013). The critical analysis of scenario construction in the Polish foresight initiatives. Technological and Economic Development of Economy, 19(3), 510-532. https://doi.org/10.3846/20294913.2013.809030

Nikmehr, B., Hosseini, M. R., Martek, I., \& Zavadskas, E. K. (2021). Digitalization as a atrategic means of achieving sustainable efficiencies in construction management: a critical review. Sustainability, 13(9), 5040. https://doi.org/10.3390/su13095040

Opricovic, S. (1998). Multicriteria optimization of civil engineering systems [PhD Thesis]. Faculty of Civil Engineering, University of Belgrade, Belgrade.

Ozturk, M., Durdyev, S., Aras, O. N., \& Banaitis, A. (2019). Productivity as a determinant of labour wage in New Zealand's construction sector. Technological and Economic Development of Economy, 25(5), 900-914. https://doi.org/10.3846/tede.2019.10297

Pasławski, J. (2008). Flexibility approach in construction process engineering. Technological and Economic Development of Economy, 14(4), 518-530. https://doi.org/10.3846/1392-8619.2008.14.518-530

Peldschus, F. (2008). Experience of the game theory application in construction management. Technological and Economic Development of Economy, 14(4), 531-545.

https://doi.org/10.3846/1392-8619.2008.14.531-545

Peldschus, F. (2009). The analysis of the quality of the results obtained with the methods of multi-criteria decisions. Technological and Economic Development of Economy, 15(4), 580-592.

https://doi.org/10.3846/1392-8619.2009.15.580-592 
Peldschus, F. (2018). Recent findings from numerical analysis in multi-criteria decision making. Technological and Economic Development of Economy, 24(4), 1695-1717. https://doi.org/10.3846/20294913.2017.1356761

Peldschus, F., \& Zavadskas, E. K. (2012). Equilibrium approaches for construction processes - multiobjective decision making for construction projects. Bauingenieur, 87(5), 210-215.

Pishdar, M., Ghasemzadeh, F., Antucheviciene, J., \& Saparauskas, J. (2018). Internet of things and its challenges in supply chain management: a rough strength-relation analysis method. E\&M Ekonomie a Management, 21(2), 208-222. https://doi.org/10.15240/tul/001/2018-2-014

Plebankiewicz, E. (2010). Simple prequalification models. Archives of Civil Engineering, 56(4), 335-351. https://doi.org/10.2478/v.10169-010-0019-4

Plebankiewicz, E., Meszek, W., Zima, K., \& Wieczorek, D. (2020). Probabilistic and fuzzy approaches for estimating the life cycle costs of buildings under conditions of exposure to risk. Sustainability, 12(1), 226. https://doi.org/10.3390/su12010226

Radziszewski, P., Nazarko, J., Vilutienè, T., Dębkowska, K., Ejdys, J., Gudanowska, A., Halicka, K., Kilon, J., Kononiuk, A., Kowalski, K. J., Król, J. B., Nazarko, Ł., \& Sarnowski, M. (2016). Future trends in road pavement technologies development in the context of environmental protection. Baltic Journal of Road and Bridge Engineering, 11(2), 60-168. https://doi.org/10.3846/bjrbe.2016.19

Rasiulis, R., Ustinovichius, L., Vilutienè, T., \& Popov, V. (2016). Decision model for selection of modernization measures: Public building case. Journal of Civil Engineering and Management, 22(1), 124-133. https://doi.org/10.3846/13923730.2015.1117018

Saoud, L. A., Omran, J., Hassan, B., Vilutienè, T., \& Kiaulakis, A. (2017). A method to predict change propagation within building information model. Journal of Civil Engineering and Management, 23(6), 836-846. https://doi.org/10.3846/13923730.2017.1323006

Sarvari, H., Chan, D. W. M., Rakhshanifar, M., Banaitiene, N., \& Banaitis, A. (2020). Evaluating the impact of building information modeling (BIM) on mass house building projects. Buildings, 10(2), 1-16. https://doi.org/10.3390/buildings10020035

Shen, K. Y., Zavadskas, E. K., \& Tzeng, G. H. (2018). Updated discussions on 'Hybrid multiple criteria decision-making methods: a review of applications for sustainability issues'. Economic ResearchEkonomska Istrazivanja, 31(1), 1437-1452. https://doi.org/10.1080/1331677X.2018.1483836

Shevchenko, G., Ustinovichius, L., \& Andruškevičius, A. (2008). Multi-attribute analysis of investments risk alternatives in construction. Technological and Economic Development of Economy, 14(3), 428443. https://doi.org/10.3846/1392-8619.2008.14.428-443

Shkundalov, D., \& Vilutienè, T. (2021). Bibliometric analysis of Building Information Modeling, Geographic Information Systems and Web environment integration. Automation in Construction, 128, 103757. https://doi.org/10.1016/j.autcon.2021.103757

Skibniewski, M. J. (2014). Information technology applications in construction safety assurance. Journal of Civil Engineering and Management, 20(6), 778-794. https://doi.org/10.3846/13923730.2014.987693

Smarandache, F. (1998). Neutrosophy: Neutrosophic probability, set, and logic: Analytic synthesis \& synthetic analysis. American Research Press.

Stankevičienè, J., \& Nikanorova, M. (2020). Eco-innovation as a pillar for sustainable development of circular economy. Business: Theory and Practice, 21(2), 531-544. https://doi.org/10.3846/btp.2020.12963

Stanujkic, D., Zavadskas, E. K., Karabasevic, D., Smarandache, F., \& Turskis, Z. (2017a). The use of the pivot pairwise relative criteria importance assessment method for determining the weights of criteria. Romanian Journal of Economic Forecasting, 20(4), 116-133.

Stanujkic, D., Zavadskas, E. K., Smarandache, F., Brauers, W. K. M., \& Karabasevic, D. (2017b). A neutrosophic extension of the MULTIMOORA method. Informatica, 28(1), 181-192.

https://doi.org/10.15388/Informatica.2017.125 
Stefano, N. M., Casarotto Filho, N., Vergara, L. G. L., \& Rocha, R. U. G. (2015). COPRAS (Complex Proportional Assessment): state of the art research and its applications. IEEE Latin America Transactions, 13(12), 3899-3906. https://doi.org/10.1109/TLA.2015.7404925

Tamosaitiene, J. (2018). Comprehensive risk assessment model in construction on agile environment. International Journal of Structural and Construction Engineering, 12(3), 366-370.

Tamošaitienė, J., Bartkiene, L., \& Vilutienè, T. (2010). The new development trend of operational research in civil engineering and sustainable development as a result of collaboration between German-Lithuanian-Polish scientific triangle. Journal of Business Economics and Management, 11(2), 316-340. https://doi.org/10.3846/jbem.2010.16

Tamošaitienė, J., Khosravi, M., Cristofaro, M., Chan, D. W., \& Sarvari, H. (2021a). Identification and prioritization of critical risk factors of commercial and recreational complex building projects: A Delphi study using the TOPSIS method. Applied Sciences, 11(17), 7906. https://doi.org/10.3390/app11177906

Tamošaitienè, J., Sarvari, H., Cristofaro, M., \& Chan, D. W. M. (2021b). Identifying and prioritizing the selection criteria of appropriate repair and maintenance methods for commercial buildings. International Journal of Strategic Property Management, 25(5), 413-431. https://doi.org/10.3846/ijspm.2021.15225

Thiel, T., \& Mroz, T. (2001). Application of multi-criterion decision aid method in designing heating systems for museum buildings. Informatica, 12(1), 133-146.

Turskis, Z. (2008). Multi-attribute contractors ranking method by applying ordering of feasible alternatives of solutions in terms of preferability technique. Technological and Economic Development of Economy, 14(2), 224-239. https://doi.org/10.3846/1392-8619.2008.14.224-239

Turskis, Z., Antuchevičiene, J., Keršuliene, V., \& Gaidukas, G. (2019a). Hybrid group MCDM model to select the most effective alternative of the second runway of the airport. Symmetry, 11(6), 792. https://doi.org/10.3390/sym11060792

Turskis, Z., Daniūnas, A., Zavadskas, E. K., \& Medzvieckas, J. (2016). Multicriteria evaluation of building foundation alternatives. Computer-Aided Civil and Infrastructure Engineering, 31(9), 717-729. https://doi.org/10.1111/mice.12202

Turskis, Z., Dzitac, S., Stankiuvienè, A., \& Šukys, R. (2019b). A fuzzy group decision-making model for determining the most influential persons in the sustainable prevention of accidents in the construction SMEs. International Journal of Computers, Communications and Control, 14(1), 90-106. https://doi.org/10.15837/ijccc.2019.1.3364

Turskis, Z., Gajzler, M., \& Dziadosz, A. (2012). Reliability, risk management, and contingency of construction processes and projects. Journal of Civil Engineering and Management, 18(2), 290-298. https://doi.org/10.3846/13923730.2012.672931

Turskis, Z., Goranin, N., Nurusheva, A., \& Boranbayev, S. (2019c). A fuzzy WASPAS-based approach to determine critical information infrastructures of EU sustainable development. Sustainability, 11(2), 424. https://doi.org/10.3390/su11020424

Turskis, Z., Urbonas, K., \& Daniunas, A. (2019d). A hybrid fuzzy group multi-criteria assessment of structural solutions of the symmetric frame alternatives. Symmetry, 11(2), 261. https://doi.org/10.3390/sym11020261

Turskis, Z., Zavadskas, E. K., \& Peldschus, F. (2009). Multi-criteria optimization system for decision making in construction design and management. Inzinerine ekonomika-Engineering Economics, 1(61), 7-17.

Ustinovichius, L., Popov, V., Cepurnaite, J., Vilutiene, T., Samofalov, M., \& Miedziałowski, C. (2018). BIM-based process management model for building design and refurbishment. Archives of Civil and Mechanical Engineering, 18(4), 1136-1149. https://doi.org/10.1016/j.acme.2018.02.004

Ustinovičius, L., \& Kochin, D. (2003). Verbal analysis of the investment risk in construction. Journal of Business Economics and Management, 4(4), 228-234.

https://doi.org/10.3846/16111699.2003.9636060 
Ustinovičius, L., Rasiulis, R., Nazarko, L., Vilutienè, T., \& Reizgevicius, M. (2015). Innovative research projects in the field of building lifecycle management. Procedia Engineering, 122, 166-171. https://doi.org/10.1016/j.proeng.2015.10.021

Vilutienè, T., \& Ignatavičius, Č. (2018). Towards sustainable renovation: key performance indicators for quality monitoring. Sustainability, 10(6), 1840. https://doi.org/10.3390/su10061840

Vilutiene, T., Kalibatiene, D., Hosseini, M. R., Pellicer, E., \& Zavadskas, E. K. (2019). Building information modeling (BIM) for structural engineering: a bibliometric analysis of the literature. Advances in Civil Engineering, 2019, 5290690. https://doi.org/10.1155/2019/5290690

Vilutiene, T., Kiaulakis, A., \& Migilinskas, D. (2021). Assessing the performance of the BIM implementation process: a case study. Revista de La Construccion, 20(1), 26-36. https://doi.org/10.7764/RDLC.20.1.26

Vilutienè, T., Kumetaitis, G., Kiaulakis, A., \& Kalibatas, D. (2020a). Assessing the sustainability of alternative structural solutions of a building: a case study. Buildings, 10(2), 36. https://doi.org/10.3390/buildings10020036

Vilutienè, T., Šarkienė, E., Šarka, V., \& Kiaulakis, A. (2020b). BIM application in infrastructure projects. Baltic Journal of Road and Bridge Engineering, 15(3), 74-92. https://doi.org/10.7250/bjrbe.2020-15.485

Vilutiene, T., \& Tamošaitiene, J. (2011). Significant scientific achievements - the result of 25 year of collaboration. Newsletter 2 of EWG ORSDCE.

Wagner, C., Zavadskas, E. K., \& Rupprecht, L. (1985). Ergebnisse der Zusammenarbeit der Wissenschaftsbereiche Technologie der HAB und des VISI. Wissenschaftliche Zeitschrift Der HAB Weimar, 3B, 91-93.

Yazdani, M., Wen, Z., Liao, H., Banaitis, A., \& Turskis, Z. (2019). A Grey Combined Compromise Solution (CoCoSo-G) method for supplier selection in construction management. Journal of Civil Engineering and Management, 25(8), 858-874. https://doi.org/10.3846/jcem.2019.11309

Zagorskas, J., \& Turskis, Z. (2020). Location preferences of new pedestrian bridges based on multicriteria decision-making and GIS-based estimation. The Baltic Journal of Road and Bridge Engineering, 15(2), 158-181. https://doi.org/10.7250/bjrbe.2020-15.478

Zavadskas, E. K. (1979). Osnovy optimizacii stroitel'nogo proizvodstva [Basics of optimization of construction production]. Vilnius.

Zavadskas, E. K. (1987). Kompleksnaja ocenka i vybor resursosberegajushhih reshenij v stroitel'stve [Complex estimation and choice of resource-saving decisions in construction]. Mokslas.

Zavadskas, E. K. (1991). Sistemotehnicheskaja ocenka tehnologicheskih reshenij [System of estimation of technological solutions in building construction]. Ctrojizdat.

Zavadskas, E. K., Antucheviciene, J., \& Turskis, Z. (2021a). Symmetric and asymmetric data in solution models. Symmetry, 13(6), 1045. https://doi.org/10.3390/sym13061045

Zavadskas, E. K., Antucheviciene, J., Turskis, Z., \& Adeli, H. (2016). Hybrid multiple-criteria decisionmaking methods: a review of applications in engineering. Scientia Iranica, 23(1), 1-20. https://doi.org/10.24200/sci.2016.2093

Zavadskas, E. K., Antuchevičienè, J., Vilutienè, T., \& Adeli, H. (2018). Sustainable decision-making in civil engineering, construction and building technology. Sustainability, 10(1), 14.

https://doi.org/10.3390/su10010014

Zavadskas, E. K., Bausys, R., Kaklauskas, A., \& Raslanas, S. (2019). Hedonic shopping rent valuation by one-to-one neuromarketing and neutrosophic PROMETHEE method. Applied Soft Computing Journal, 85, 105832. https://doi.org/10.1016/j.asoc.2019.105832

Zavadskas, E. K., Baušys, R., \& Lazauskas, M. (2015). Sustainable assessment of alternative sites for the construction of a waste incineration plant by applying WASPAS method with single-valued neutrosophic set. Sustainability, 7(12), 15923-15936. https://doi.org/10.3390/su71215792 
Zavadskas, E. K., Kaklauskas, A., Peldschus, F., \& Turskis, Z. (2007). Multi-attribute assessment of road design solutions by using the COPRAS method. The Baltic Journal of Road and Bridge Engineering, 2(4), 195-203.

Zavadskas, E. K., Kaklauskas, A., \& Vilutiene, T. (2009). Multicriteria evaluation of apartment blocks maintenance contractors: Lithuanian case study. International Journal of Strategic Property Management, 13(4), 319-338. https://doi.org/10.3846/1648-715X.2009.13.319-338

Zavadskas, E. K., Peldschus, F., \& Kaklauskas, A. (1994). Multiple criteria evaluation of projects in construction. Technika.

Zavadskas, E. K., \& Turskis, Z. (2011). Multiple criteria decision making (MCDM) methods in economics: an overview. Technological and Economic Development of Economy, 17(2), 397-427. https://doi.org/10.3846/20294913.2011.593291

Zavadskas, E. K., Turskis, Z., \& Kildienė, S. (2014). State of art surveys of overviews on MCDM/MADM methods. Technological and Economic Development of Economy, 20(1), 165-179. https://doi.org/10.3846/20294913.2014.892037

Zavadskas, E. K., Turskis, Z., Šliogerienè, J., \& Vilutiene, T. (2021b). An integrated assessment of the municipal buildings' use including sustainability criteria. Sustainable Cities and Society, 67, 102708. https://doi.org/10.1016/j.scs.2021.102708

Zavadskas, E. K., Turskis, Z., \& Tamošaitiene, J. (2010). Risk assessment of construction projects. Journal of Civil Engineering and Management, 16(1), 33-46. https://doi.org/10.3846/jcem.2010.03

Zavadskas, E. K., Ustinovichius, L., \& Peldschus, F. (2003). Development of software for multiple criteria evaluation. Informatica, 14(2), 259-272. https://doi.org/10.15388/Informatica.2003.020

Zavadskas, E. K., Ustinovičius, L., \& Turskis, Z. (2002). Levi 3.0 - multiple criteria evaluation program for construction solutions. Journal of Civil Engineering and Management, 8(3), 184-191. https://doi.org/10.1080/13923730.2002.10531275

Zhang, L., Wu, X., Ding, L., Skibniewski, M. J., \& Lu, Y. (2016). BIM-based risk identification system in tunnel construction. Journal of Civil Engineering and Management, 22(4), 529-539.

https://doi.org/10.3846/13923730.2015.1023348 